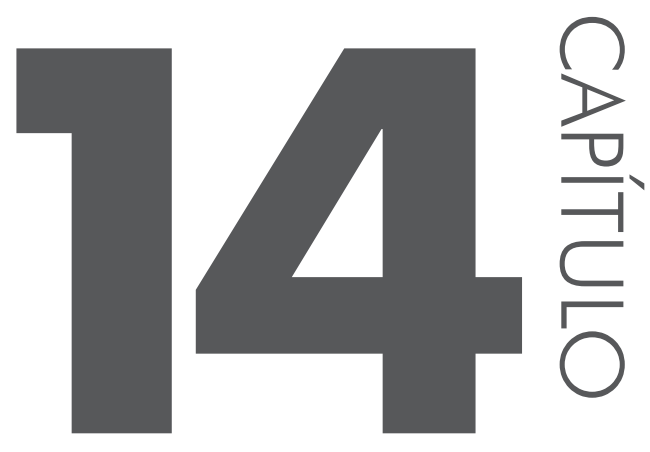

\title{
A relação das línguas com a construção do Estado-nação angolano
}

\section{Heloísa Tramontim de Oliveira}

Doutoranda do Programa de Pós-Graduação em Linguística/UFSC

- Queres dizer que qualquer nacionalismo provoca racismo?

- No nosso caso (angolano), ou no de África em geral,o nacionalismo é uma fase necessária e vale a pena lutar por ele. Não ponho isso em dúvida. Mas provoca também exclusões injustas. E, se exagerado, leva as sociedades a fecharem-se sobre si próprias e a não aproveitarem do progresso de outros povos.

Diálogo entre Laurindo e Sara, em “A Geração da Utopia”. Pepetela, 1992.

Muitos estudos sobre políticas linguísticas modernas dedicam-se ao conceito e à construção dos Estados nacionais. Tal fato é atribuído à ideia de "unidade" que se vincula a essa construção: uma língua, um povo, uma nação. Os nacionalistas angolanos que contestaram vigorosamente a política de alienação cultural, procedente do colonialismo português, em detrimento do nascimento do "homem novo" e de uma "angolanidade", que se encontrava até então oprimida, tiveram que se haver com a decisão de construção de um novo Estado independente. A 
língua portuguesa, até então cenário de muitos conflitos e objeto originário de dominação e estímulo para as disputas em prol da nacionalização, foi, então, nomeada como a língua oficial de Angola, na justificativa de reduzir "os conflitos linguísticos-interétnicos e estabelecer relações internacionais fundadas numa língua comum" (JORGE, 2013, p. 119).

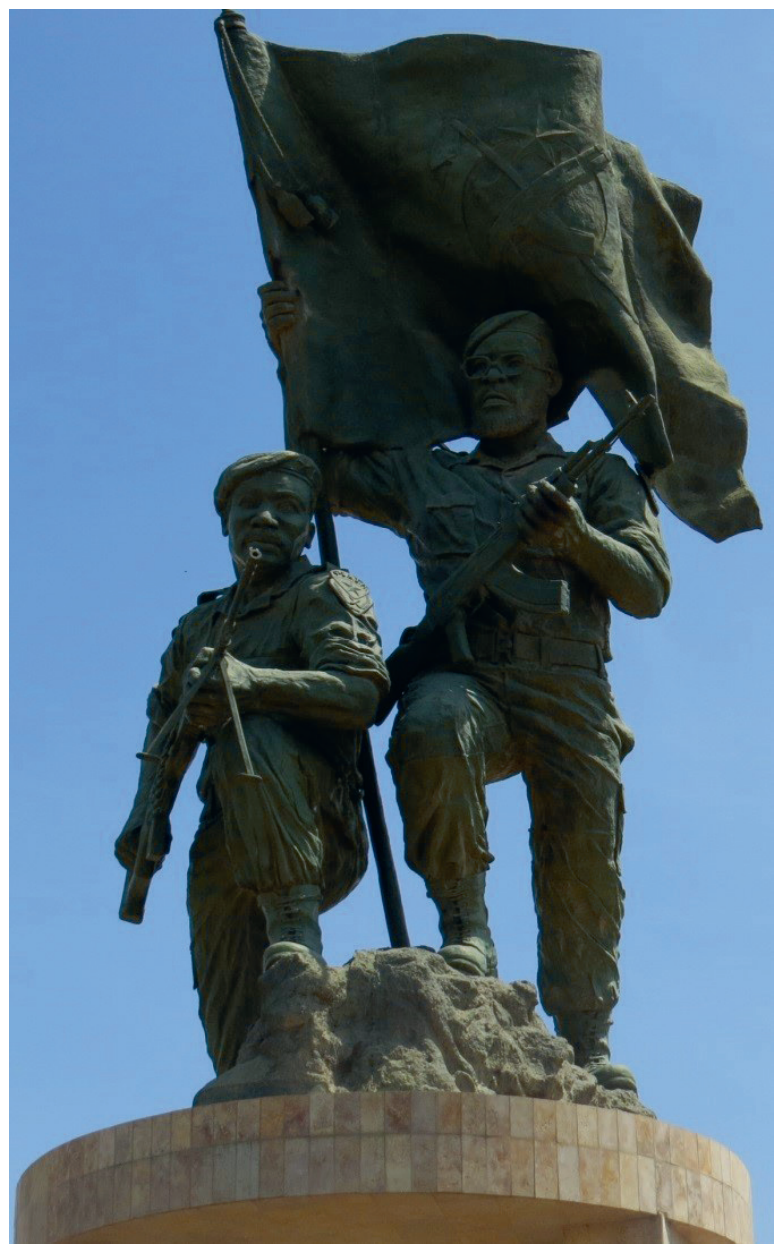

Figura 14.1 -Da luta pela Independência. Fonte: foto de llka Boaventura Leite, 2012.

A língua, bem como a literatura e a história, é um dos três grandes pilares de sustentação da identidade e da cultura nacionais. O papel político da língua em relação à construção de nação se tornou forte na época da instauração dos Estados modernos, cujo projeto, com o intuito de unificar para melhor governar, sobrepôs língua e nação (ANDERSON, 2008).

A questão principal a ser levantada neste capítulo não trata apenas da esco- 
lha política instaurada pela seleção de uma língua em detrimento de outras, da língua portuguesa ao invés de uma das línguas nacionais. O que nos cabe problematizar, diante do contexto multilíngue de Angola é: por que a escolha tem que se pautar em apenas uma única língua? E por que a língua se tornou alvo de discursivização, seja pela religião, pelos partidos políticos, pelas políticas internacionais? Afinal, por que a língua foi posta em debate?

Sobre tais questões, procuraremos fomentar uma discussão sobre as características de unificação que permeiam o discurso sobre nação e nacionalismo e problematizar a resistência dos Estados e dos sujeitos em desconstruir tal discurso.

\section{Nação e nacionalismo: conceituação}

Os conceitos de nação e nacionalismo explorados aqui baseiam-se nas propostas feitas por Benedict Anderson, em Comunidades Imaginadas (2008), e por Edward Said, em Cultura e Imperialismo (2011). O primeiro autor define nação como "uma comunidade política imaginada - e imaginada como sendo intrinsecamente limitada e, ao mesmo tempo, soberana" (ANDERSON, 2008, p. 32). A partir dessa definição, Anderson se aprofunda na explicação de quatro termos caros à nação: imaginada, limitada, soberana e comunidade. A saber:

- a nação é imaginada porque mesmo os membros da mais minúscula das nações jamais conhecerão, encontrarão ou nem sequer ouvirão falar da maioria de seus companheiros, embora todos tenham em mente a imagem viva da comunhão entre eles;

- imagina-se a nação limitada porque, mesmo a maior delas, que agregue, digamos, um bilhão de habitantes, possui fronteiras finitas, ainda que elásticas, para além das quais existem outras nações;

- imagina-se a nação soberana porque o conceito nasceu na época em que o Iluminismo e a Revolução estavam destruindo a legitimidade do reino dinástico hierárquico de ordem divina. Porque as nações sonham em ser livres, a garantia e o emblema dessa liberdade é o Estado soberano;

- a nação é imaginada como uma comunidade porque, independentemente da desigualdade e da exploração efetivas que possam existir dentro dela, a nação é sempre concebida como uma profunda camaradagem horizontal.

O autor, na mesma obra, afirma que é no tocante à camaradagem, ou ao sentimento de fraternidade entre tantos sujeitos - os quais se dispuseram não tanto a matar, mas a morrer pela nação - que encontraremos a resposta das raízes culturais do nacionalismo. Utilizamos a definição de Said (2011), por sua vez, a fim de 
pensar o nacionalismo que se insurge contra o imperialismo colonial. De acordo com o autor, o "nacionalismo" em si carrega um valor simbólico totalizante, com capacidade de designar todo tipo de coisas indiferenciadas, e cumpre um papel de força mobilizadora, a qual se transformou em resistência contra um império exterior de ocupação, por parte de povos que possuíam uma história, uma religião e uma língua comuns. Mas, apesar de ter conseguido - ou justamente porque conseguiu - libertar muitos territórios do domínio colonial, o nacionalismo permaneceu como uma iniciativa extremamente problemática.

Exemplos desse aspecto problemático foram os protestos a favor de um nacionalismo angolano que reuniam líderes provenientes das elites burguesas em parte formadas, e até certo ponto criadas, pelo poder colonial. As burguesias nacionais e suas elites especializadas tenderam a substituir a força colonial por uma nova força de tipo classista, em última análise exploradora, que reproduzia as velhas estruturas coloniais em novos termos, gerando novas formas de poder. Além disso, os horizontes culturais de um nacionalismo podem ser fatalmente limitados pela história comum que ele pressupõe para o colonizador e o colonizado. O imperialismo, afinal, foi um empreendimento conjunto, e um traço marcante de sua forma moderna alegava ser um movimento educacional; ele se propôs expressamente a modernizar, desenvolver, instruir e civilizar (SAID, 2011).

A proposta de Anderson (2008) pauta-se no entendimento do nacionalismo alinhando-o não a ideologias políticas conscientemente adotadas, mas aos grandes sistemas culturais que o precederam, e a partir dos quais ele surgiu, inclusive para combatê-los. A nação em modelo de bloco veio a reboque de cimentar as diferenças existentes em Angola, na tentativa de totalizar para unir. De acordo com Makoni e Meinhof (2006), Anderson não considera o construto de língua como algo problemático. Entretanto, na esteira dos argumentos sobre nação e nacionalismo de Anderson (2008) e da definição de nacionalismo de Said (2011), lança-se mão, neste capítulo, não de combater, mas de problematizar a maneira como as línguas foram usadas como bandeiras políticas na formação do Estado-nação angolano.

\section{O surgimento do nacionalismo angolano}

Os angolanos uniram-se em diferentes agrupamentos nacionalistas e pró-independência que se baseavam em um sentimento de identidade étnica, religiosa ou comunal e se opuseram a um avanço da usurpação ocidental. Isso aconteceu desde o início dos movimentos de libertação. Tais movimentos tornaram-se uma realidade global no século XX por ter sido uma reação tão disseminada ao avanço europeu. Os sujeitos, com poucas exceções, uniram-se em afirmações de sua resistência àquilo que percebiam como uma prática injusta contra eles, sobretudo 
por serem o que eram, ou seja, não ocidentais. Aconteceu que tais agrupamentos fossem às vezes ferozmente exclusivistas (SAID, 2011), como demonstraram muitos historiadores do nacionalismo angolano.

Em 1971, o termo “África portuguesa” encontrava-se na contramão das lutas anticolonialistas empreendidas pelos nacionalistas. Por conta disso, o historiador David Birmingham criou o termo "África lusófona” que, apesar de ser aderido pela mídia, foi recusado novamente pelos movimentos nacionalistas:

Quando a expressão “África Portuguesa” parecia inadequada para territórios onde largas porções da população estavam em rebelião contra Portugal, cunhei o termo “África Lusófona” que foi rapidamente adoptado pelos media e governos estrangeiros, embora não o fosse pelos movimentos nacionalistas que se referem embaraçosamente às suas nações como "países de língua oficial portuguesa" (BIRMINGHAM, 2010, p. 199).

Podemos encontrar uma explicação para a recusa feita por parte dos nacionalistas ao termo proposto por Birmingham em Makoni et al. (2012). Os autores afirmam que o discurso da lusofonia é utilizado para descrever áreas geograficamente associadas à língua portuguesa. A essência desse termo descritivo, no entanto, jamais fará jus à tapeçaria linguística (p. 526) da África. Ao invés disso, o uso desse termo ressalta a prevalência de antigos idiomas coloniais às custas do multilinguismo complexo que existe nessas regiões. O termo lusofonia reflete a natureza de como a política funciona, além de constituir formas de perceber o panorama sociolinguístico africano sob uma perspectiva oficial.

\section{O papel das línguas no surgimento dos partidos políticos angolanos}

Quando os movimentos de libertação foram surgindo, a língua configurou uma das grandes propulsoras na veiculação de ideias. Uma repulsa ao colonizador falante de língua portuguesa se estendeu aos falantes africanos de língua portuguesa, principalmente aos assimilados, e o "tribalismo" foi se assentando nas diferenças políticas veiculadas por línguas diferentes, formando cisões políticas territoriais.

Por esse motivo, a relação entre as línguas e os partidos angolanos é importante para se entender o cenário político de Angola. Enquanto outras colônias, em seus processos de independência, tinham como ponto central a capital e um partido político que se empenhava em opor-se ao governo colonial vigente, em Angola, a busca pela libertação foi embalada não só por confrontos políticos de angolanos contra portugueses, mas também de angolanos contra angolanos (BIR- 
MINGHAM, 2010; SEVERO, 2015a). A dispersão etnolinguística local abriu possibilidades para o nascimento de três movimentos políticos que marcaram a libertação de Angola: o Movimento Popular de Libertação de Angola (MPLA), a Frente Nacional de Libertação de Angola (FNLA) e a União Nacional para a Independência Total de Angola (UNITA).

Os partidos se encontravam em três regiões distintas de Angola, e cada qual se caracterizava por uma distribuição étnica e linguística diferente. Segundo Birmingham (2010), a capital e seu interior, ao longo do corredor para Malanje, estavam unidos por um rio, uma estrada de ferro, por uma rede metodista de escolas e capelas, por uma triste história de invasores e traficantes ibéricos de pessoas, pela ascensão de uma elite e, principalmente, pela língua kimbundu falada pelo povo com etnia de mesmo nome. Esse centro, onde originou-se o Movimento Popular de Libertação de Angola (MPLA), não estava ligado nem com Angola do Norte, nem com Angola do Sul. Cada região tinha seu próprio centro metropolitano: ao norte, na cidade colonial belga de Leopoldville, atual Kinshasa, se encontrava a Frente Nacional de Libertação de Angola (FNLA); e ao sul, no terminal ferroviário britânico do Lobito, se localizava a União Nacional para a Independência Total de Angola (UNITA). Não foi por acidente que Angola desenvolveu três movimentos políticos, em vez de um único. De fato, desenvolveram-se inicialmente três movimentos políticos (MPLA, FNLA e UNITA) com três pontos urbanos fulcrais e três concentrações de diferentes línguas, faladas por três agrupamentos rivais dirigidos por líderes nacionalistas distintos, assentados cada um em uma região.

O MPLA foi o movimento que deu origem ao partido de mesmo nome, proveniente de Luanda e arredores, e era composto pelos quimbundos (20\% da população) e pela elite de Luanda falante de língua portuguesa (MENEZES, 2000). Liderado por Agostinho Neto, foi o partido que chegou ao poder depois da independência. Por conta disso, contamos com uma vasta literatura em português sobre a história da formação do movimento, a literatura que representava os revoltosos, bem como as relações políticas que tinham com o comunismo soviético e cubano.

O FNLA foi a frente que deu origem ao partido de mesmo nome; inicialmente denominava-se UPA, União das Populações de Angola. Liderada por Holden Roberto, a frente originou-se no norte de Luanda e se estabeleceu em Kinshasa, capital do antigo Zaire, hoje República Democrática do Congo. Composta pelo grupo étnico bacongo (15\% da população), o terceiro maior grupo de Angola, ocupava os territórios de Cabinda e as províncias do norte, além de estar também presente no Congo e no Zaire (MENEZES, 2000). Entre várias línguas, configura como predominante do FNLA o uso do kikongo. Os angolanos que ali viviam foram buscar melhores oportunidades fora de Angola, que há muito era oprimida pela exploração colonial do Império Português. Depois disso, se instalaram no 
Zaire, província que recebeu esse nome devido às influências exercidas pelo antigo país onde viviam.

A UNITA, oriunda de uma cisão da FNLA, localizava-se no centro e no sul de Angola. Contava com forte presença da etnia ovimbundo (a maior do país), que fala a língua umbundo, entre outras. Ocupam, sobretudo, o Planalto Central de Angola, nas províncias de Huambo, Benguela e Bié, mas se espalharam por todo o país (MENEZES, 2000). Contava com a liderança Jonas Savimbi, o qual foi morto na última guerra entre os partidos.

De acordo com Correira (1991), o sistema colonial português nunca permitiu o desenvolvimento da luta política nacionalista, nem em Angola e nem em nenhuma das outras colônias. Todas as tentativas de organização, de doutrinação, de diálogo, foram severa e violentamente reprimidas, impedindo que a fase da luta de libertação se quedasse pelo nível da luta política. Mas a vontade nacionalista e independentista assumiu uma dinâmica irreversível, e a repressão política empurrou-a, sem remédio, para o patamar da luta armada, que viria a evoluir para uma guerra prolongada de libertação nacional.

As diferenças e os interesses conflitantes entre os nacionalistas foi um problema quase tão significativo quanto a própria luta contra o colonizador opressor (MENEZES, 2000). Na base dessas diferenças, situavam-se não apenas vaidades pessoais e disputas políticas, mas profundas distâncias ligadas à histórica relação entre as muitas tribos e etnias africanas. Tratava-se de politizar grupos rurais provenientes de diferentes etnias em torno da ideia de nacionalismo, especialmente em um país extremamente dividido e multifacetado em termos de línguas, povos e cultura, segundo Henriksen (1977 apud SEVERO, 2015a).

Assim, observa-se a existência de três movimentos nacionalistas distintos em Angola, sendo que um deles - que deu origem ao MPLA - encontra-se em posição de nítido destaque em relação aos demais. A evidência dada a esse nacionalismo defendido pelo MPLA pode ser explicitamente constatada, tanto na relevância de certas obras de literatura angolana como no grande valor conferido aos seus escritores, todos intelectuais que deram origem ou fizeram parte do MPLA. Esse reconhecimento não implica uma crítica à importância desses trabalhos ou de seus autores, ou mesmo de conferir-lhes qualquer espécie de desprestígio, mas apenas o reconhecimento que o ideário de nação também é construído pelas expressões literárias de um país, sendo que as expressões nem sempre revelam uma mesma visão e, tampouco, fazem jus à pluralidade local. No caso do MPLA, esse ideário nacionalista estava geopoliticamente localizado na área central do território angolano, desfavorecendo outras visões de nação, as quais remetem aos territórios periféricos e aos não falantes de língua portuguesa, os quais foram alvo de outros dois partidos políticos: a FNLA e a UNITA. 
Um dos papéis da língua na divisão política de Angola dizia respeito à rivalidade entre o MPLA e a FNLA. Os segundos usavam habitualmente o francês como sua língua franca. Os apoiantes da FNLA eram predominantemente do norte, e uma grande parte tinha vivido no Zaire por muitos anos, a fim de aproveitar as oportunidades econômicas do local. Em relação às lutas nessa região, no ano de 1961, em Angola, houve uma revolta independentista na região portuguesa do café, resultando em uma chacina colonial, como podemos constatar no trabalho de José Freire Antunes, intitulado A Guerra de África 1961-1974:

De madrugada, na Fazenda Primavera, perto de São Salvador, grupo de bacongos,
empunhando catangas e canhangulos e julgando-se imunes às balas dos brancos,
lançam uma ofensiva contra propriedades e povoações na zona de fronteira com o
Congo, na Baixa de Cassange, até às cercanias de Vila Carmona. O Norte de An-
gola é avassalado por uma onda de brutalidade tribal, assassínios em massa, incên-
dios, destruições e rapina de haveres, violações de mulheres e crianças. Os tumultos
espalham-se às plantações de café isoladas, aos postos de abastecimento e às vias de
transporte.

Muitos nortistas que ali viviam emigraram para o Zaire e encontraram novas oportunidades entre seus irmãos étnicos, os quais já lá viviam. À medida que os novos angolanos iam prosperando, enviavam seus filhos a escolas francesas e preenchiam com eles os nichos econômicos negligenciados pelos zairenses. Quando os filhos de angolanos, nascidos no Zaire, voltavam à terra dos pais falando francês, eram chamados de "zairotas" (BIRMINGHAM, 2010), alcunha utilizada para marcar e rebaixar o "outro", o não utente da língua portuguesa.

Apesar da alcunha aos “angolanos-zairenses”, muitos desses que chegavam à capital ocupavam cargos de trabalho abandonados pelos imigrantes de Portugal, os quais para lá retornaram dominados pelo pânico de mais uma guerra civil, em 1975. Na verdade, nada mais se assemelhava à economia urbana de Angola que o dinamismo desenfreado de Kinshasa, de onde tantos retornados angolanos tinham vindo. As oportunidades eram tantas que os "zairotas" francófonos não conseguiram preencher todas as vagas deixadas pelos portugueses fugidos, e outros imigrantes começaram a ser atraídos para Luanda, levados pela prosperidade alimentada pelo petróleo:

Nessas circunstâncias, a cidade aprendeu a viver com os retornados e com seus modos "franceses" estranhos, mas também com suas necessárias competências urbanas. Troçavam deles por seu espírito de clã, por não falarem corretamente o português, por serem um enclave masculino que parasita as mulheres locais com ofertas de bens materiais e porque estavam do lado errado da linha de batalha no 10 de novembro de 1975, dia em que todo o verdadeiro Luandense, ele ou ela, se lembra do que estava 
a fazer quando as armas bombardeavam os subúrbios. Mas são tolerados. A atitude em relação aos imigrantes do campo é bastante diferente (BIRMINGHAM, 2010, p. 203).

A relação dos luandenses com os imigrantes do campo é diferente, pois não falavam "a mesma língua”. Ainda que os chamados de "zairotas" exercessem seus "estranhos" costumes, estes estavam de acordo com o costume do europeu, por também falarem a língua francesa. Dessa maneira, os "zairotas" estavam, ideologicamente, a "falar a mesma língua" do luandense, ou seja, assemelhavam-se àqueles que sofreram o processo de assimilação. $\mathrm{O}$ mesmo não pode ser averiguado, no entanto, em relação aos migrantes rurais falantes das línguas angolanas:

$\mathrm{Na}$ cidade, os imigrantes rurais são tratados com desprezo notório, sobretudo aqueles que não falam português ou que não adoptam comportamentos europeizados. [...] As pessoas do campo vêm de todas as partes do país, mas sobretudo do corredor de Luanda de língua kimbundu ao longo da linha do caminho-de-ferro para Malanje e do planalto de língua umbundu (BIRMINGHAM, 2010, p. 203).

Esse exemplo clarifica o quanto o conceito de nação falha como empreendimento fixo, pois desliza. O julgamento feito pelos luandenses sobre os angolanos vindos do Zaire ${ }^{58}$ e sobre os angolanos vindos do campo é distinto. A língua europeia dos sujeitos vindos do Zaire ainda é mais valorizada que as línguas de origem angolana. Podemos perceber aqui que não é a língua que vem a reboque do nacionalismo, e sim o oposto.As guerras entre MPLA, FNLA, UNITA e as Forças Armadas de Portugal iniciaram em 1961. Segundo Kanda (2005), as rivalidades entre os movimentos e a disputa de algumas zonas de influência logo resvalaram para os confrontos armados. Muito cedo os movimentos se revelaram incapazes de unir seus esforços numa frente comum. As cisões no seio dos partidos e as lutas entre si beneficiaram Portugal, na medida em que enfraqueciam o movimento nacionalista.

No ano de 1975, a guerra terminou, e o MPLA chegou ao poder. Com o apoio internacional das tropas cubanas e tendo Agostinho Neto como presidente, instaurou-se um governo de orientação nacionalista-marxista que contou com o Brasil como o primeiro país a reconhecer a independência. Esse reconhecimento, paradoxalmente, possibilitou um estreitamento de laços políticos entre os dois países, em uma época em que o Brasil vivia sob um regime ditatorial. Os dois outros partidos não marxistas, não aceitando a condição do MPLA no poder, iniciaram um longo processo de guerras civis que só terminaria em 2002, após a morte do líder da UNITA, Jonas Savimbi.

58 Atual República Democrática do Congo. 
A relevância política da língua portuguesa depois da independência tornou-se ainda mais crucial em Angola. A língua tornou-se um signo central de rivalidade política, de confronto ideológico, de facciosismo regional, de descontentamento rural, de confronto de classes e de interferência neocolonial (BIRMINGHAM, 2010). O Brasil proclamava ser neutro, equânime, capaz de aceitar a vitória final de qualquer dos três movimentos guerrilheiros que lutavam em Luanda. De acordo com o diplomata responsável pelo reconhecimento da independência de Angola por parte do Brasil, Ovídio de Andrade Melo (2009), era facílimo supor, desde o início, que o MPLA de Agostinho Neto, apoiado, entre outros países, pela URSS, seria o movimento afinal vencedor. Contudo, os Estados Unidos e certos países europeus não reconheceriam Angola independente. Nessa mesma direção, os partidos da direita, a grande imprensa, a televisão, os brasileiros lusófilos e os portugueses salazaristas no Brasil fariam tudo, do possível ao absurdo, para impedir que também o Brasil reconhecesse o novo país.

A ideia de nacionalismo acaba por arraigar a valorização das línguas historicamente prestigiadas e o desprezo pelas línguas angolanas. Relembramos que as línguas não são uma abstração, um dado em si, mas "existem em relação às práticas discursivas e linguísticas das pessoas, o que implica considerar aquilo que as pessoas efetivamente fazem com as línguas” (SEVERO, 2015a, p. 84).

Esses movimentos, por conta das sobreposições etnolinguísticas instauradas na época colonial, se insurgiram em diferentes pólos, também subdivididos em diferentes interesses e reivindicações sobre a própria pátria. O sentimento de nacionalidade, proveniente de um ideal de nação angolana, doravante chamado de “angolanidade", não se apresentava único em oposição à imposição colonial, mas fragmentado e fortemente diferenciado etnolinguística e politicamente.

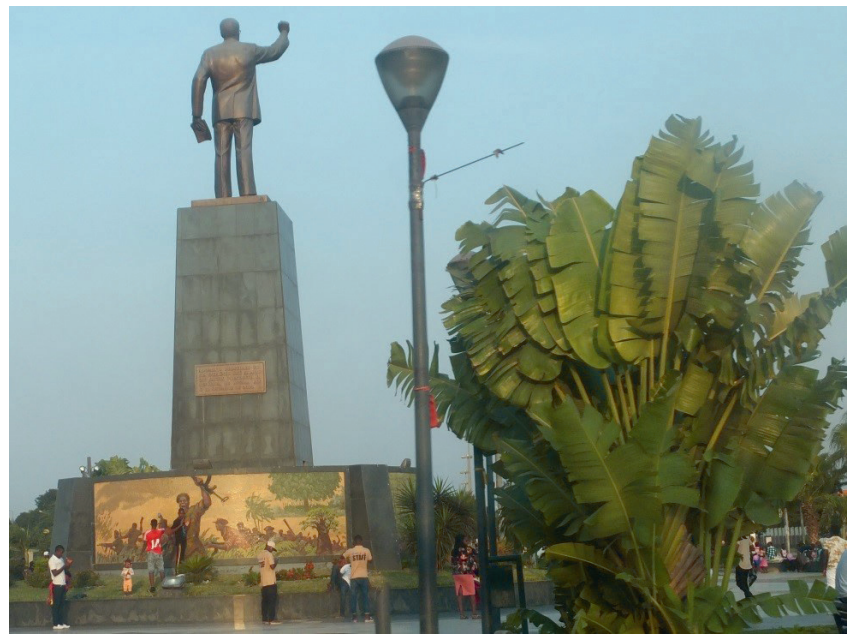

Figura 14.2 -Estátua de Agostinho Neto. Fonte: foto de Nazareno Campos, 2014. 


\section{Angolanidades}

De acordo com Patrício Batsîkama (2013), há três distintas dinâmicas de ideologizações sobre a ideia de "angolanidade", entendida como a "idealização ou a tentativa de teorização sobre o Estado-nação angolano". Essas ideologizações moldaram três identidades do país, que floresceram em três épocas diferentes: a angolanidade apriorística (1961-1975); a angolanidade rizomática e angolanitude (1975-1992); e angolanidade aposteriorística (1992-2002). Interessa, para este capítulo, contudo, somente as duas primeiras, que coincidem com os momentos históricos aqui contemplados.

Conforme já vimos, a língua portuguesa desempenhou papel diferente em relação a esses modelos de angolanidade, pois, enquanto o partido do MPLA concebia sua adoção como forma de unificar o país evitando possíveis "tribalismos", os partidos FLNA e UNITA, por sua vez, encaravam tal adoção como atitude submetida a uma possível neocolonização por parte da elite burguesa angolana, que já não dominava mais os usos das línguas locais.

De acordo com os pressupostos de Batsîkama (2013), a angolanidade apriorística foi amplamente sustentada pelo MPLA no projeto sobre Angola como Estado-nação, e sua premissa consistiu em agregar as partes, fazendo de Angola um lugar onde "todos os angolanos constituam uma só nação; um só povo" (BATSÎKAMA, 2013). Partiu-se do pressuposto que o povo angolano estaria acima das etnias, abrindo espaço para angolanos, africanos e europeus viverem como um só povo. Para isso, utilizariam a língua portuguesa como uma medida de neutralizar as diferenças entre as etnias. Diferentemente, a angolanidade rizomática e angolanitude, energicamente sustentada pela FNLA e readaptada pela UNITA, afirmava que a construção de Angola como Estado-nação precisaria partir das raízes culturais africanas. Em busca de um modelo africano que rompesse com a colonização em prol da independência total, no que diz respeito à cultura colonial, o angolano de "fora" (euro-angolano) seria um convidado, secundarizado. A angolanidade posteriorística, por sua vez, contemplaria todos os partidos que surgiram a partir dos anos 1990 e expressam mplaísmo como forma de "construir um país que o MPLA destruiu” (BATSÎKAMA, 2013).

\section{O multilinguismo como um "problema" para o Estado Novo angolano}

A língua, nesse viés, afetou significativamente os movimentos literários e culturais das comunidades, bem como a criação de símbolos e mitos nacionais, os quais foram fazendo nascer uma pré-consciência nacional ou um sentido de autonomia ou de intervenção no sistema colonial, antes da independência do território, e que se mantiveram ou se transmutaram na fase de independência (TOR- 
GAL; PIMENTA; SOUSA, 2008). Mais do que qualquer outra comunidade, as nações requerem para sua sobrevivência a construção de uma identidade coletiva, para contrabalançar os muitos elementos divergentes que todas têm de enfrentar. Construir essa identidade requer escrever e reescrever a história e, com isso, criar heróis nacionais, mitos, símbolos e alegorias que, por vezes, produz apagamentos, "recalques" e invisibilizações:

O 'nacionalismo' é a patologia da história do desenvolvimento moderno, tão inevitável quanto a 'neurose' no indivíduo, e que guarda muito da mesma ambiguidade de essência, da tendência interna de cair na loucura, enraizada nos dilemas do desamparo imposto à maior parte do mundo (o equivalente do infantilismo para as sociedades), sendo em larga medida incurável (TOM NAIRN apud Anderson, 2008, p. 31).

De acordo com Schwarcz (2008) são três as instituições fundamentais que moldam as imaginações nacionalistas: os censos, os mapas e os museus, que

juntas, criaram realidades unificadas, por mais distintas que fossem; categorias raciais claras em territórios onde os grupos se misturavam e se fundiam; histórias sequenciais e lógicas; mapas e fronteiras fixos. [...] Com essas operações comuns, e ordenadas, os dados retirados dos censos, dos museus e dos mapas passaram a ser signo puro, e não mais bússolas do mundo (SCHWARCZ, 2008, p. 14-15).

O Estado Novo de Angola expressou sua soberania com hinos nacionais, bandeiras e comícios, que Eric Hobsbawn (2015, p. 326) diz serem típicos da Europa do século XIX: "representando estados territoriais multiétnicos, as nações africanas estão muito menos envolvidas na invenção de 'culturas nacionais' do que estavam os românticos escoceses ou galeses”. Tais símbolos, no entanto, foram necessários como atestados de autenticidade, gerando, assim, os patrimônios da nova nação. A língua única, por meio de sua normatização, ajudou a configurar, desse modo, um patrimônio imaterial extremamente necessário na vinculação das ideias do nacionalismo, principalmente quando mobilizada por discursos, pelo ensino e pela literatura.

De acordo com Said (2011), a oposição e o questionamento metropolitanos foram imprescindíveis para os personagens, para a linguagem e para a própria estrutura da resistência nativa ao imperialismo. A sobreposição da cultura em oposição à política, à história militar e ao processo econômico não foi algo desprezível ou insignificante. A mesma cultura que predispôs uma sociedade a preparar-se para o domínio ultramarino de outra sociedade pôde também inclinar essa primeira sociedade à renúncia e à modificação dessa ideia de domínio ultramarino. Tal renúncia ao colonialismo e mudança, no entanto, não aconteceriam sem a contrapartida da sociedade dominada, que deu um passo decisivo em rela- 
ção à resistência contra o domínio colonial, seja pegando em armas, concebendo ideias de libertação ou mesmo imaginando uma nova comunidade nacional. Por conta disso, foi mister a decisão de colocar em prática a construção de uma nova nação angolana, para fazer com que a metrópole reconhecesse a independência e a identidade da cultura angolana, sem mais intromissões coloniais. Tal atitude não ocorreu sem a instalação de uma exaustão política e econômica, bem como sem o questionamento público dos problemas impostos pelo domínio colonial, o qual colocou em cheque as representações do imperialismo português, fazendo perder sua justificação e legitimidade (SAID, 2011).

Sobre os processos de construção de uma nação, segundo Said (2011), depois do período de "resistência primária", literalmente lutando contra a intromissão externa, surge o período de "resistência secundária", isto é, ideológica, quando se tenta reconstituir uma "comunidade estilhaçada, salvar ou restaurar o sentido e a concretude da comunidade contra todas as pressões do sistema colonial”, como diz Basil Davidson (1964), citado por Said. Isso, por sua vez, possibilita a instauração de novos interesses independentes. Davidson (apud Said, 2011) menciona as promessas "supraterrenas" feitas por alguns intelectuais na fase inicial do nacionalismo, por exemplo, rejeitando o cristianismo e o uso de roupas ocidentais. Apesar das diferenças, todos os intelectuais reagem às humilhações do colonialismo, e levam ao "principal ensinamento do nacionalismo: a necessidade de encontrar a base ideológica para uma unidade mais ampla do que qualquer outra que jamais existiu”, segundo Davidson (1964 apud SAID, 2011, p. 329).

$\mathrm{Na}$ maioria dos países africanos, tornou-se patrono econômico neocolonial o poder "paleo-colonial" (BIRMINGHAM, 2010, p. 198). Entende-se esse conceito como a conjuntura de uma nação mais forte explorar uma nação mais fraca, usando os recursos públicos desta e enriquecendo aquela, por meio da interferência direta em seus assuntos políticos, econômicos e culturais, a fim de dominar recursos, trabalho e mercado do território colonial. Esse modelo alcunha-se como segundo modelo de descolonização, o qual diz respeito a padrões tradicionais de parceria neocolonial. A primeira contiguidade inusitada dada pelo governo do MPLA é a da posição consolidada da língua portuguesa. Durante a luta de libertação, o português foi um dos fatores de unificação que manteve o MPLA ligado.

No que tange as relações entre Brasil e Angola, o governo brasileiro, que desperdiçou tanto tempo acobertando a ganância dos colonialistas portugueses e ignorando as aspirações do povo angolano, buscou ter em Luanda um representante perante os três movimentos guerrilheiros, para melhor conhecê-los e planejar as relações futuras entre os dois países. O Brasil, nesse caso, era neutro entre os movimentos, e tinha, de acordo com Ovídio de Andrade Melo, "uma política que se poderia definir como machadiana: ao vencedor, as batatas. Assim, entre os partidos disputantes, aquele que fosse o vencedor, seria reconhecido como go- 
verno futuro" (2009, p. 14). Juracy Magalhães, nomeado embaixador do Brasil em 1964, já havia proclamado, no entanto, que "o que era bom para os Estados Unidos, era bom para o Brasil” (MELO, 2009, p. 36). Os Estados Unidos, na época, precisavam das bases nos Açores e, por essa razão, continuavam votando a favor de Portugal em sua obtusa teimosia colonialista portuguesa sobre o continente africano, tão somente como a África do Sul do apartheid e o Brasil (MELO, 2009).

Devemos também concentrar-nos no argumento intelectual e cultural no âmbito da resistência nacionalista segundo o qual, uma vez adquirida a independência, novas e imaginativas reconcepções da sociedade e da cultura eram necessárias para se evitar as velhas ortodoxias e injustiças. Na esteira desse argumento, que defendia a equalização das raças, a totalização das etnias foi engendrada pela totalização linguística.

O conceito de língua nacional é fundamental, mas, sem a prática de uma cultura nacional - das palavras de ordem aos panfletos e jornais, dos contos folclóricos aos heróis e à poesia épica, aos romances e ao teatro - a língua é inerte; a cultura nacional organiza e sustenta a memória comunal, como quando as primeiras derrotas nas histórias da resistência africana são retomadas; ela repovoa a paisagem usando modos de vida, heróis, heroínas e façanhas restauradas; formula expressões e emoções de orgulho e de desafio que, por sua vez, formam a coluna vertebral dos principais partidos independentistas nacionais. Narrativas locais dos escravos, autobiografias espirituais e memórias da prisão proporcionam um contraponto às histórias monumentais, aos discursos oficiais e ao ponto de vista panóptico aparentemente científico das potências ocidentais (SAID, 2011, p. 333-334).

A escolha de apenas uma língua oficial foi respaldada por práticas sociais de rememoração, as quais procuraram instalar como base os principais elementos do seio da tradição que adotou uma língua que possibilitasse o relevo de uma etnia sobre outra em Angola. O resgate memorial da tradição angolana configurou-se como mais uma criação para cimentar os ideais nacionais. Segundo Fanon (2008, p. 215), entretanto, entendemos que as tradições jamais seriam as mesmas:

Pensamos que a luta organizada e consciente empreendida por um povo colonizado para estabelecer a soberania da nação, constitui a manifestação mais plenamente cultural que existe. Não é unicamente o triunfo da luta que dá validade e vigor à cultura, não existe hibernação da cultura durante o combate. A luta, no seu desenvolvimento, no seu processo interno, faz progredir as diferentes direcções da cultura e esboça outros caminhos. A luta de libertação não restitui à cultura nacional o seu valor e os seus antigos contornos. Esta luta, que tende para uma redistribuição fundamental das relações entre os homens, não pode deixar intactas as formas nem os conteúdos culturais desse povo. Depois da luta não desaparece apenas o colonialismo, mas desaparece também o colonizado. 
Quando Angola alcançou a Independência e se tornou uma nação pela lógica dos Estados modernos, sua tapeçaria linguística acabou por se tornar um "problema" para os ideais nacionalistas, principalmente no que diz respeito à escolha de apenas uma língua. Os conceitos básicos de língua herdados pela ideologia do Estado-nação se referem ao lema "uma nação, uma língua, uma cultura" (RAJAGOPLAN, 2008), não eram condizentes ao contexto africano plurilinguístico e, portanto, incapazes de corresponder à realidade dos povos ali viventes, pois, como dizem Fardon e Furniss (1994), o multilinguismo é a língua franca da África. Esse multilinguismo, quando confrontado com o modelo nacional, torna-se um problema.

Segundo Fardon e Furnis (1994), considerando que a capacidade do multilinguismo pode ser elogiada em outros lugares, permite-se enfatizar, sob a ótica da unicidade, que a complexidade linguística presente em África passe a ser vista como um problema. Vejamos que tal problema não é dado pela carência, mas pelo excesso. Se existe uma língua, existe, supostamente, uma solução. O multilinguismo africano prejudicaria uma governamentabilidade centrada na ideia de Estado nacional. Por conta disso, Angola adotou o modelo monolíngue europeu, ou seja, a língua portuguesa como bandeira de unificação do país diante de uma realidade multiétnica e multilíngue (SEVERO, 2011).

Contudo, a alternativa de se escolher uma língua angolana para representar a nação teve logo que ser descartada por razões políticas. Por um lado, seria necessário existir alguma língua em sua forma escrita padronizada para fazer as documentações burocráticas necessárias para formalizar um país independente, caso que não procedia. Nem se poderia começar imediatamente a ensinar tal língua nas escolas sem a sua estandardização. Por outro lado, caso a normatização de uma dada língua angolana se realizasse postumamente, ainda assim a decisão de escolher uma entre as várias línguas angolanas terminaria por fomentar o tribalismo, o qual já se apresentava como um problema anterior à independência. Alguns teóricos levantaram a questão de que a escolha da língua do colonizador, após a independência colonial, consistiria num ato neocolonial. No entanto, a problemática dessa questão não é tão simples. Todas essas escolhas e decisões não são atos de cunho linguístico, mas, sim, político.

A lógica ocidental, de sobreposição etnolinguística, proveio da demarcação instaurada nos Estados europeus, os quais compreendiam divisões territoriais baseadas em um povo que falava determinada língua. No entanto, tais demarcações fixas de propriedade territorial não obedeciam às relações que os africanos tinham com o seu território. De acordo com Hobsbawn (2015), os europeus estavam completamente equivocados no que diz respeito às suas interpretações sobre as sociedades africanas pré-coloniais. Pensavam que os africanos sentiam extrema valoração em relação à fixidez territorial, de tradição e de costumes, mesmo que 
tais formas fixas tivessem sido também inventadas pelos europeus. $\mathrm{O}$ autor ainda ressalta que a identidade tribal única estava longe de existir, pois "a maioria dos africanos assumia ou rejeitava identidades múltiplas, definindo-se em certos momentos como súditos de um chefe, em outros como membros de certa seita, em outros, ainda, como membros de um clã, e em outros momentos como iniciantes numa categoria profissional" (HOBSBAWN, 2015, p. 310).

Podemos atestar essa "contralógica" a respeito da fixidez territorial (e também cultural) ao tomarmos como exemplo os kuvale, os pastores do Namibe, cuja principal característica confere-se às práticas do nomadismo (CARVALHO, 2000). Por conta disso, a divisão e nomeação dos povos em "aldeias" ou em "tribos", delimitados também por divisão e nomeação das línguas "nativas", caracteriza-se como obra política do empreendimento colonial que visava dividir para melhor governar. Tal divisão fomentou os mesmos problemas de lutas territoriais já vividas pelos europeus, que recebeu em África o nome de "tribalismo".

A ideia de tribalismo emergiu a partir da instauração dos dispositivos de panoptismo (FOUCAULT, 2013; HALL, 2013; SAID, 2011) colonial, instalado a serviço de estratificar ao máximo para melhor controlar. Essa concepção de “tribo", como nos aponta Hall (2013, p. 32), possui uma identidade cultural de "concepção fechada, um núcleo imutável e atemporal, ligando ao passado o futuro e o presente numa linha ininterrupta”. A mesma ideia que o europeu tinha de nação, pensava também ter o africano em relação à tribo. Hobsbawn, citando John Iliffe, aborda a "criação das tribos" na Tanganica colonial, onde os administradores alemães acreditavam que:

[...] todo africano pertencia a uma tribo, assim como todo europeu pertencia a uma nação. [...] As tribos eram consideradas unidades culturais possuidoras de uma linguagem comum, um sistema social único, e um direito comum estabelecido. [...] As diferentes tribos relacionavam-se em termos genealógicos (2015, p. 313).

Essa adoção da "unidade tribal” da nação deu espaço ao surgimento da governança indireta. Como donos do poder, criaram uma dada geografia política. Os problemas de "tribalismo", originados pelo empreendimento colonial, implicam fatores diversos, tais como: artificialidade das fronteiras; as diversas línguas e etnias existentes no espaço e o fato de elas não coincidirem com as referidas fronteiras; os problemas da colonização, que são fatores formadores e deformadores do "espírito nacional"; a formação, a ação e as cisões diversas de grupos anticolonialistas armados em defesa da independência, que se mantiveram depois dela, assim como, em alguns casos, as suas características guerreiras de luta violenta pelo poder; a influência política e econômica de outros países - como sistemas políticos capitalistas e comunistas - antes e depois da independência, entre outros 
fatores (HALL, 2013). Os Estados-nação impuseram fronteiras rígidas dentro das quais esperava-se que as culturas florescessem. Esse foi o relacionamento primário entre as comunidades políticas nacionais soberanas e suas "comunidades imaginadas". Foi também o referencial adotado pelas políticas nacionalistas e de construção de nação após a independência (HALL, 2013).

Nesse contexto nacionalista, quando tratamos de planejamento linguístico em Angola, remontamos ao fato de um país que não fala a língua portuguesa em sua totalidade. A categoria de Estado-nação tem frequentemente sido usada para se referir ao pós-colonialismo em África (MAKONI et al., 2012). Infelizmente, apesar da importância do Estado-nação como uma heurística analítica, sua importância para as políticas linguísticas não foi rigorosamente analisada em políticas de planejamento linguístico. O Estado-nação serve como um fulcro a partir do qual as políticas linguísticas são descritas. Por exemplo, políticas agora são entendidas em termos de políticas linguísticas brasileiras, políticas linguísticas portuguesas, políticas linguísticas angolanas etc. Mesmo que a análise do Estado-nação seja importante, sua conceituação e a avaliação de políticas linguísticas em Angola vão, portanto, sendo complicadas pela extensão a que as políticas de planejamento linguístico estejam parcialmente implementadas. Essa extensão acaba complicando a implementação porque os Estados-nação variam em tamanho, recursos e grau de estabilidade política. E as políticas linguísticas no caso angolano se depararam com a questão de, na época da independência, nem ao menos 30\% da população falar a língua do colonizador.

\section{A "lusofonia" e o problema da língua única}

O uso de algumas terminologias como "lusofonia" ou "países lusófonos”, por parte de órgãos como a Comunidade dos Países de Língua Portuguesa (CPLP) ou Países Africanos de Língua Oficial Portuguesa (PALOP), sugere uma teoria discrepante das práticas. Em Angola, o multilinguismo existe, muito embora o discurso oficial encapsulado no termo lusofonia sugira que a as políticas linguísticas sejam primariamente monolíngues. Ao referir-se às nações com o termo autoexplicativo "países de língua oficial portuguesa”, apesar de não esconder o estatuto de oficialidade da língua, acaba-se por sugerir a não oficialidade de outras línguas. Além disso, as línguas "nativas" mudaram sob o impacto do cristianismo, pois palavras velhas assumiram significados novos devido à tendência de as traduções cristãs usarem palavras já existentes para descrever conceitos cristãos, em vez de optar por neologismos (MAKONI; MEINHOF, 2006).

Assim, podemos indagar a respeito das línguas angolanas: quão "autênticas" são essas línguas nativas? Os relatos dos intelectuais e políticos angolanos sobre a autenticidade não são convincentes para as pessoas do campo, já que elas enten- 
dem que os proponentes de tal visão, dos que falam a língua portuguesa, vivem muito melhor, ainda que de forma nada autêntica, apropriando-se dos signos de autenticidade dos lugares de onde são originários (MAKONI et al., 2012). Essa preocupação não era, no entanto, ignorada pelas premissas do MPLA depois de se instalar no poder. Podemos averiguá-la em diferentes excertos do discurso do primeiro presidente, Agostinho Neto, no dia Dia da Cultura Nacional, proferido em 8 de janeiro de 1979:

A cultura do povo angolano é hoje constituída por pedaços que vão das áreas urbanas assimiladas às áreas rurais apenas levemente tocadas pela assimilação cultural europeia. E porque as capitais como a nossa, agigantadas pela burocracia exercem um feito mágico sobre a maior parte do país, existe a tendência para a imitação, claramente visível no aspecto cultural. Daí uma responsabilidade muito especial da União dos Escritores Angolanos.

$[\ldots]$

É necessário o mais alargado possível debate de ideias, o mais amplo possível movimento de investigação, dinamização, apresentação pública de todas 88 formas culturais existentes no país, sem qualquer preconceito de caráter artístico ou linguístico. Façamos os artistas populares criar! Seria necessário longo tempo para dizer aqui que para falar para o povo angolano, é preciso ser um elemento do povo angolano. Não é questão de língua, mas de qualidade nacional. (NETO, 1979).

Havia por parte do então presidente, Agostinho Neto, uma preocupação em valorizar os sujeitos angolanos e as suas línguas, no entanto, tal preocupação ainda era cunhada em torno do ideal político de nação. Além disso, o que as elites intelectuais africanas definiram como autêntico, não o é, muitas vezes, do ponto de vista das pessoas pobres que vivem em áreas rurais, conforme salientado por Makoni et al. (2012). Assim, torna-se importante situar a ideia de autenticidade em discursos africanos mais amplos. Infelizmente, os discursos de autenticidade com os quais as populações nativas estão alinhadas foram inventados e apropriados pelo MPLA, bem como por outros movimentos políticos. É assim que "em qualquer caso, as culturas sempre se recusaram a ser perfeitamente encurraladas dentro das fronteiras nacionais. Elas transgridem os limites políticos” (HALL, 2013, p. 39).

Muitas pesquisas em políticas linguísticas se pautam pela construção de alfabetos e inscrição de letramentos, garantindo, dessa maneira, a indexação de línguas orais. Essas tarefas são empregadas com vistas de formalizar as línguas e garantir a "salvação" ou "manutenção" da cultura dos utentes dessas línguas. Essa proliferação das práticas de descrição linguística, no entanto, faz emergir 
diferenças entre línguas que antes não existiam, pois apagam as nuances no processo de indexação para a criação de uma normativa (MAKONI; MEINHOF, 2006). Além disso, sob o prisma etnolinguístico, o funcionamento dessa lógica que sobrepõe e confunde etnia e língua acaba por figurar apenas um trabalho que encerra em si. Além de não fazer valer os direitos dos falantes dessas línguas, essa demarcação corre o risco de demarcar fronteiras e erguer barreiras entre essas etnias e essas línguas.

O resultado de Angola ser mais um entre os países integrantes do bloco lusófono acaba por esconder sua realidade multilíngue e multiétnica, criando a ilusão de ser um país monolíngue diante dos olhares estrangeiros. A criação de instituições internacionais como a CPLP reforça esta situação. De acordo com Severo (2014), a existência de uma língua só é reconhecida nas práticas locais de interações, e toda política linguística deve ser antes de tudo uma política que garanta a existência de diferentes formas de expressão linguística e cultural dos diferentes grupos étnicos numa dada sociedade. A língua portuguesa, embora seja oficial, de prestígio social, dificilmente poderá aniquilar as línguas consideradas nacionais ou locais. Além disso, os encontros linguístico-discursivos possibilitam a hibridização da língua portuguesa com as línguas nacionais num processo de apropriação, conferindo a emergência da variedade angolana do português.

Diante do exposto, podemos perceber que o ideal de nação falha no que diz respeito à consideração das diferenças angolanas. Ao tentar encaixar todos os sujeitos em uma só proposição, acaba por se ignorar a grande maioria. Como o ideário de nação é construído a partir de uma lógica eurocêntrica, resvala ao considerar a realidade e a necessidade do povo angolano. A real libertação angolana precisaria considerar sua própria natureza plural. A independência nacionalista, que apesar de ter sido cara em um dado momento, já não acompanha mais a demanda do povo. Como diz Fanon (2008), a transformação da consciência social tem de ir para além da consciência nacional. Trata-se de se libertar de uma vez por todas da política monolinguística instaurada pelo ideal nacionalista que visa contribuir com a instauração da nação. O rompimento com o ideário nacional desfaz a ideia de unidade e transpassa os limites imaginários da comunidade. Sob uma nova abertura, indaga-se a respeito da necessidade de uma normativa linguística sobre as línguas nacionais, pela fixação da língua, uma vez que, de acordo com Fardon e Furniss (1994), a indexação de uma língua de cunho oral permite a sua artificialização. A partir do momento em que as línguas africanas são pesquisadas, analisadas e descritas sob moldes e conceitos das línguas europeias, acontece significativa redução e relevante apagamento das línguas pesquisadas em sintonia com a emergência das metáforas conceituais coloniais (MAKONI; MEINHOF, 2006). Assim, segundo Lima (2014, p. 217), é necessário “supor que hoje, o que pode ser entendido como 'línguas nacionais' não é algo natural, neutro ou auto-evidente". O fato de as línguas "nativas" terem sido socialmente construídas 
produz implicações linguísticas importantes. Assim, uma vez que as línguas são socialmente construídas, precisam ser desconstruídas de tempos em tempos, para que se tornem tão compreensíveis quanto possível (MAKONI; MEINHOF, 2006).

É dado que os Estados-nação são constituídos de sua própria história política, seus conflitos e sua geografia linguística. Por conta dessas influências, o que caracteriza uma política linguística "bem-sucedida" para um Estado-nação deve ser avaliado em relação à complexidade do pano de fundo de outro Estado-nação, fronteiriço, por exemplo. Exemplo de relações linguísticas transfronteiriças é que um número relativamente grande de grupos etnolinguísticos cruza fronteiras políticas variadas sem, contudo, perder sua capacidade de compreensão mútua. Portanto, pelos Estados-nação serem definidos por fronteiras fixas, as políticas linguísticas devem procurar ser avaliadas em relação à porosidade dessas fronteiras e de suas histórias e geografias políticas, tentando compreender não só as suas, mas as outras formas de conflito.

\section{Conclusão}

Relativizando o sentido de unidade nesse capítulo, não há apenas uma angolanidade. Essa ideia é também veiculada à ideia de tradição como construção política. De acordo com Gilroy (2007), é impossível considerar apenas a ideia de nação para pensar em modernidade, pois o que se tem são divisões coloniais, uma vez que a geopolítica foi demarcada arbitrariamente. Assim, ao invés de pensarmos na fixidez dos Estados-nação, podemos pensar em sua mobilidade, onde se transita, para além do limite da nação. A lógica em questão é o trânsito e a transição das fronteiras, sobretudo para as questões linguísticas. Assim, acreditamos que essa realidade fluida e plural precisa intervir nas políticas linguísticas.

\section{Referências}

ANDERSON, B. Comunidades Imaginadas: reflexões sobre a origem e a difusão do nacionalismo. São Paulo: Companhia das Letras, 2008.

BATSÎKAMA, P. Angolanidade: construção das identidades angolanas. Por dentro da África, 2013. Disponível em: < http://www.pordentrodaafrica.com/wp-content/uploads/ kalins-pdf/singles/angolanidade-construcao-das-identidades-angolanas-por-patricio-batsikama.pdf>. Acesso em: 4 fev. 2016.

BIRMINGHAM, D. Portugal e África. Tradução de Arlindo Barbeitos. Lisboa: Nova Vega, 2010.

CARVALHO, R. D. Vou lá visitar pastores: exploração epistolar de um percurso angolano em território Kuvale. Rio de Janeiro: Gryphus, 2000. 
CORREIA, P. Descolonização de Angola. Lisboa: Inquérito, 1991.

DAVIDSON, B. The african past: Chronicles from antiquity to modern times. Londres: Longmans, 1964.

FANON, F. Pele negra, máscaras brancas. Tradução de Renato da Silveira. Salvador: EDUFBA, 2008.

FARDON, R.; FURNISS, G. African languages, development and the state. London: Routledge, 1994.

FOUCAULT, M. Vigiar e punir: nascimento da prisão. Tradução de Raquel Ramalhete. 41. ed. Petrópolis: Vozes, 2013.

GILROY, P. O Atlântico negro: modernidade e dupla consciência. Tradução de Cid Knipel Moreira. São Paulo: Editora 34; Rio de Janeiro: Universidade Candido Mendes, 2007.

HALL, S. Da Diáspora: Identidades e mediações culturais. Belo Horizonte: UFMG, 2013.

HOBSBAWN, E.; RANGER, T. A invenção das tradições. Tradução de Celina Cardim Cavalcante. São Paulo: Paz e Terra, 2015.

JORGE, M. Evolução e estrutura da nação e do Estado nos países africanos de língua oficial portuguesa (PALOP). Mulemba, v. 3, n. 6. Luanda: Edições Mulemba, 2013.

KANDA, A. Repensar a História de Angola. Uige: Sedipu, 2005.

LIMA, I. S. Língua nacional, histórias de um velho surrão. In: LIMA, I. S.; CARMO, L. (Org.). História social da língua nacional. Rio de Janeiro: Edições Casa de Rui Barbosa, 2008.

MAKONI, S.; MEINHOF, U. Linguística aplicada na África: Desconstruindo a Noção de Língua. In: MOITA LOPES, L. P. Por uma linguística aplicada indisciplinar. São Paulo: Parábola Editorial, 2006.

MAKONI, B.; ABDELHAY, A.; MASHIRI, P. Colonial and post colonial language policies in Africa. In: SPOLSKY, Bernanrd. The Cambridge handbook of language policy. New York: Cambridge University Press, 2012.

MELO, O. A. Recordações de um removedor de mofo no Itamaraty. Brasília, DF: Fundação Alexandre de Gusmão, 2009.

MENEZES, S. Mama Angola: sociedade e economia de um país nascente. São Paulo: Edusp, 2000.

NETO, A. Discurso à união dos escritores angolanos no dia da cultura nacional. 1979. Disponível em: <http://www.agostinhoneto.org/index.php?option=com_content $\&$ view= 
article $\& i d=748:$ discurso-dia-da-cultura\&catid=48: discursos\&Itemid=232>. Acesso em: 27 fev. 2016.

PEPETELA. A geração da utopia. São Paulo: LeYa, 2013.

RAJAGOPALAN, K. Por uma linguística crítica: linguagem, identidade e a questão ética. São Paulo: Parábola Editorial, 2008.

SAID, E. W. Cultura e imperialismo. Tradução de Denise Bottman. São Paulo: Companhia das Letras, 2011.

SCHWARCZ, L. M. Imaginar é difícil (porém necessário). In: ANDERSON, B. Comunidades imaginadas: reflexões sobre a origem e a difusão do nacionalismo. São Paulo: Companhia das Letras, 2008.

SEVERO, C. G. Línguas e discurso: heterogeneidade linguístico-discursiva e poder em Angola. Veredas, 2011.

. Línguas e Estados nacionais: problematizações históricas e implicações. In: SEVERO, C.; SITOE, B.; PEDRO, J. Estão as línguas nacionais em perigo? Lisboa: Escolar Editora, 2014.

SEVERO, C.; MAKONI, S. Políticas linguísticas Brasil-África: por uma perspectiva crítica. Florianópolis: Insular, 2015. (Coleção Linguística, v. 5).

TORGAL, L. R.; PIMENTA, F. T.; SOUSA, J. S. Comunidades imaginadas: nação e nacionalismo em África. Coimbra: Imprensa da Universidade de Coimbra, 2008. 